\title{
PENERAPAN DATA MINING UNTUK MENGANALISA POLA PERMINTAAN PEMASANGAN CCTV DENGAN MENGGUNAKAN METODE MARKET BASKET ANALYSIS STUDY KASUS CV. MITRA JAYA PERKASA
}

\author{
Ramadhan Pandapotan Siringo-Ringo, Melda Panjaitan
}

\author{
Program Studi Teknologi Informatika STMIK Budi Darma, Medan, Indonesia
}

Emil: ramdhan.pandapotans@gmail.com

\begin{abstract}
Abstrak
CV. MITRA JAYA PERKASA merupakan perusahaan yang bergerak dalam jasa pemasangan cctv dimana permintaan pemasangan cctv menjadi salah satu faktor pentingnya. Oleh sebab itu sangatlah penting untuk mengetahui pola permintaan pemasangan cetv agar dapat menyesuaikan dengan stok gudang dan keterkaitan barang cetv. Dengan bantuan komputer dapat dijadikan salah satu solusi permasalahan, dimana dengan dibangunnya sebuah sistem data mining yang merupakan program komputer berbasis pengetahuan yang menyediakan solusi untuk masalah dan mendapatkan informasi dari gudang data yang besar. Dalam hal ini perusahaan dapat menganalisa pola permintaan pemasangan cctv dengan menggunakan metode market basket analysis. Diharapkan data mining ini dapat memberikan informasi pola permintaan pemasangan cctv dan menyesuaikan stok gudang. Hasil dari penelitian ini adalah sebuah aplikasi yang dapat membantu menganalisa pola permintaan pemasangan cctv dan menganalisa keterkaitan barang yang menggunakan metode market basket analysis.
\end{abstract}

Kata kunci: Data Mining, Market Basket Analysis, Pola Permintaan pemasangan cctv.

\section{Abstract}

CV. MITRA JAYA PERKASA is a company engaged in CCTV installation services where demand for CCTV installation is one of the important factors. Therefore it is very important to know the cctv installation request pattern so that it can adjust to the warehouse stock and the cctv goods linkage. With the help of computers can be used as a solution to the problem, where by building a data mining system which is a knowledge-based computer program that provides solutions to problems and get information from large data warehouses. In this case the company can analyze the cctv installation request pattern using the market basket analysis method. It is expected that this data mining can provide information on the cctv installation request pattern and adjust the warehouse stock. The results of this study are an application that can help analyze the cctv installation request patterns and analyze the relationship of goods using the market basket analysis method.

Keywords: Data Mining, Market Basket Analysis, cctv installation request patterns.

\section{PENDAHULUAN}

CCTV atau ( Closed Circuit TeleVision ) sebuah camera video digital yang difungsikan untuk memantau dan mengirimkan sinyal video pada suatu ruang yang kemudian sinyal itu akan diteruskan ke sebuah layar monitor. CCTV sangan berguna dalam pemantauan keadaan dalam suatu tempat yang berhubungan dalam keamanan dan tindak kejahatan.Instalasi pemasangan CCTV biasanya berasal dari permintaan dari pelanggan. Dalam setiap pemasangan berbeda - beda dalam segi jenis kamera dan jumlahnya. Jika tidak di lakukan penyesuaian stok kamera terhadap jenis kamera yang diminta dari setiap pelanggan bisa menimbulkan pengaruh besar terhadap pelayanan. Dan begitu juga kalau minimnya stok kamera dapat berpengaruh terhadap pelayanan pelanggan dan pendapatan dari perusahaan.

Data tidak dapat dipisahkan dari kehidupan sehari hari dan merupakan salah satu sumber daya yang sangat berharga. Suatu perusahaan besar maupun kecil dapat memiliki suatu data yang sangat penting, tidak terkecuali dengan perusahaan CV. Mitra jaya perkasa. Data - data yang terlibat dalam setiap transaksi pemasangan CCTV pada perusahaan tersebut ini, seperti data item yang pesan oleh pelanggan, waktu pembelian, jumlah item yang dibeli, harga item, data konsumen dan data pelanggan. Berlatar belakang pada permasalah diatas, penulis melakukan analisa data dengan menggunakan teknik Market Basket Analysis atau sering juga disebut Asociation rule. Dengan adanya teknik ini kita dapat mengidentifikasi hubungan antara item dan kita juga dapat menentukan item mana saja yang paling sering dibeli sekaligus item mana saja yang sering dibeli secara bersamaan. Setelah proses identifikasi maka kita dapat mengetahui pola permintaan pemasangan cctv. Pola-pola atau rules yang diperoleh nantinya dapat dijadikan acuan dalam menentuan penyusunan letak item secara rapi menurut kombinasi barang yang paling sering dibeli ,saling berhubungan dan dapat menyesuaikan stoke camera terhadap kersediaan item di gudang, dengan tujuan meningkatkan pelayanan dan penjualan barang dengan strategi pemasaran yang tepat.

Berdasarkan jurnal dengan judul “Analisa Data Mining Menggunakan Market Basket Analysis untuk Mengetahui Pola Beli Konsumen" dapat disimpulkan bahwa Metode Market Basket Analysis ( Rule Association ) dengan algoritma apriori ini dapat digunakan untuk membantu toko bangunan saiyo mengetahui pola beli konsumen dan item yang sering dibeli konsumen[1]. Berdasarkan jurnal dengan judul " Penerapan Metode Data Mining Market Basket Analysis Terhadap Data Penjualan Produk Pada Toko Oase Menggunakan Algoritma Apriori" dapat disimpulkan bahwa hubungan hubungan keterkaitan barang yang satu dengan barang yang lainnya, dan dari hubungan-hubungan keterkaitan tersebut digunakan untuk mengatur penempatan barang, pengaturan penempatan barang dapat diketahui melalui support dan nilai confidence. Barang-barang yang memiliki nilai support tinggi posisi 
penempatannya ditempatkan diawal/ujung karena barang - barang tersebut merupakan barang barang yang sering dibeli oleh pembeli. Sedangkan barang-barang yang memiliki nilai confidence tinggi diletakkan bersebelahan karena dengan tingginya nilai confidence antara kedua barang atau lebih memiliki kesempatan dibeli secara bersamaan yang tinggi[2].

\section{TEORITIS}

\subsection{Data Mining}

Data Mining adalah proses yang mempekerjakan satu atau lebih teknik pembelajaran komputer (machine learning) untuk menganalisa dan mengekstrak pengetahuan secara otomatis. Defenisi lain diantaranya adalah pembelajaran berbasis induksi (induction-based learning) adalah proses pembentukan defenisi-defenisi konsep umum yang dilakukan dengan cara mengobservasi contoh-contoh spesifik dari konsep-konsep yang akan dipelajari.

Data Mining berisi pencarian trend atau pola yang diinginkan dalam database besar untuk membantu pengambilan keputusan diwaktu yang akan datang. Pola-pola ini dikenali oleh perangkat tertentu yang dapat memberikan suatu analisa data yang berguna dan berwawasan yang kemudian dapat dipelajari dengan lebih teliti, yang mungkin saja menggunakan perangkat pendukung keputusan lainnya[3].

Kesimpulan dari data mining adalah disiplin ilmu yang mempelajari metode untuk mengekstrak pengetahuan atau menenukan pola dari suatu data sehingga sering disebut Knowledge Discovery in Database.

\subsection{Market Basket Analysis}

Association Rule sering juga disebut dengan Market Basket Analysis karena kegunaannya dalam pembuatan model perilaku pembelian oleh konsumen. Association Rule adalah suatu prosedur dalam analisis keranjang pasar (Market Basket Analysis) untuk menentukan aturan asosiasi yang memenuhi syarat minimum untuk support dan confidence ( minimum support dan minimum confidence). Analisis assosiation rule mining adalah teknik data mining untuk menemukan aturan assosiatif antara suatu kombinasi item. Algoritma aturan assosiasi akan menggukan data latihan, sesuai dengan pengertian Data Mining, untuk menghasilkan pengetahuan.

Association Rule merupakan salah satu metode yang bertujuan mencari pola yang sering muncul di antara banyak transaksi, dimana setiap transaksi terdiri dari beberapa item sehingga metode ini akan mendukung system rekomendasi melalui penemuan pola antar item dalam transaksi - transaksi yang terjadi metodologi dasar analysis asosiasi terbagi menjadi dua tahap

1. Analisa pola prekuensi tinggi

Tahap ini mencari kombinasi item yang memenuhi syarat minimum dari nilai support dalam database. Nilai support sebuah item diperoleh dengan rumus berikut :

Support $(\mathrm{A})=\underline{\text { Jumlah Transaksi Mengandung A }}$

$$
\text { Total Transaksi }
$$

Sedangkan nilai support dari 2 item diperoleh

Rumus berikut :

Support $(\mathrm{A}, \mathrm{B})=\underline{\text { Jumlah Transaksi Mengandung A dan B }}$

$$
\text { Total Transaksi }
$$

2. Pembentukan aturan assosiatif

Setelah semua pola frekuensi tinggi ditemukan, barulah dicari aturan assosiatif yang memenuhi syarat minimum untuk confidence dengan menghitung confidence aturan assosiatif A_B Nilai confidence dari aturan A_B di peroleh rumus sebagai berikut :

$$
\text { Confidence } \mathrm{P}(\mathrm{B} / \mathrm{A})=\frac{\text { Jumlah Transaksi Mengandung A dan B }}{\text { Jumlah Transaksi Mengandung A }}
$$

\subsection{Permintaan}

Permintaan adalah jumlah barang atau jasa yang ingin dan mampu dibeli oleh konsumen. Permintaan adalah salah satu faktor yang sangat penting dalam pemasangan CCTV agar dapat menyesuaikan ketersediaan stok barang dalam sebuah perusahaan.

\section{ANALISA DAN PEMBAHASAN}

\subsection{Analisa}

Analisa sistem adalah penguraian dari suatu sistem informasi yang utuh kedalam bagian-bagian komponennya dengan maksud untuk mengidentifikasikan dan mengevaluasi permasalahan, kesempatan, dan hambatan yang terjadi dalam kebutuhan yang diharapkan sehingga dapat diusulkan perbaikannya. 
Dalam melihat pola permintaan konsumen yang ada di CV. Mitra Jaya Perkasa menggunakan banyak metode. Metode yang sering digunakan dalam melihat pola permintaan konsumen yaitu dari laporan transaksi produk.

Pola permintaan konsumen dari laporan transaksi pembelihan dilihat dari lapotan pembelian produk, dari laporan tersebut pemilik menganalisa dengan membandingkan dengan laporan penjualan setiap periode dengan itu pemilik dapat melihat pola permintaan dari peroduk yang di inginkan konsumen. Untuk menentukan produk yang dipilih pemilik hanya dapat memilih satu atau beberapa produk tanpa ada keterkaitan antar produk tersebut.

Metode yang digunakan dalam penyelesaian ini adalah metode Market Basket Analysis. Metode market basket analysis merupakan metode yang paling pertama menyaring produk dengan tingkat asosiasi antar produk. Produk yang dihasilkan dari metode market basket analysis ini tidak hanya menghasilkan tingkat produk yang berhubungan.

Proses analisan pola permintaan konsumen diawali dengan pengambilan data transaksional, data transaksi yang diambil pada periode tertentu dengan data mining menggunakan metode market basket analysis dan untuk mengetahui asosiasi berupa tingkat support dan confidence produk.

Flowchart dari metode Market Basket Analysis untuk menganalisa pola permintaan pemsangan cctv pada CV. Mitra Jaya Perkasa sebagai berikut.

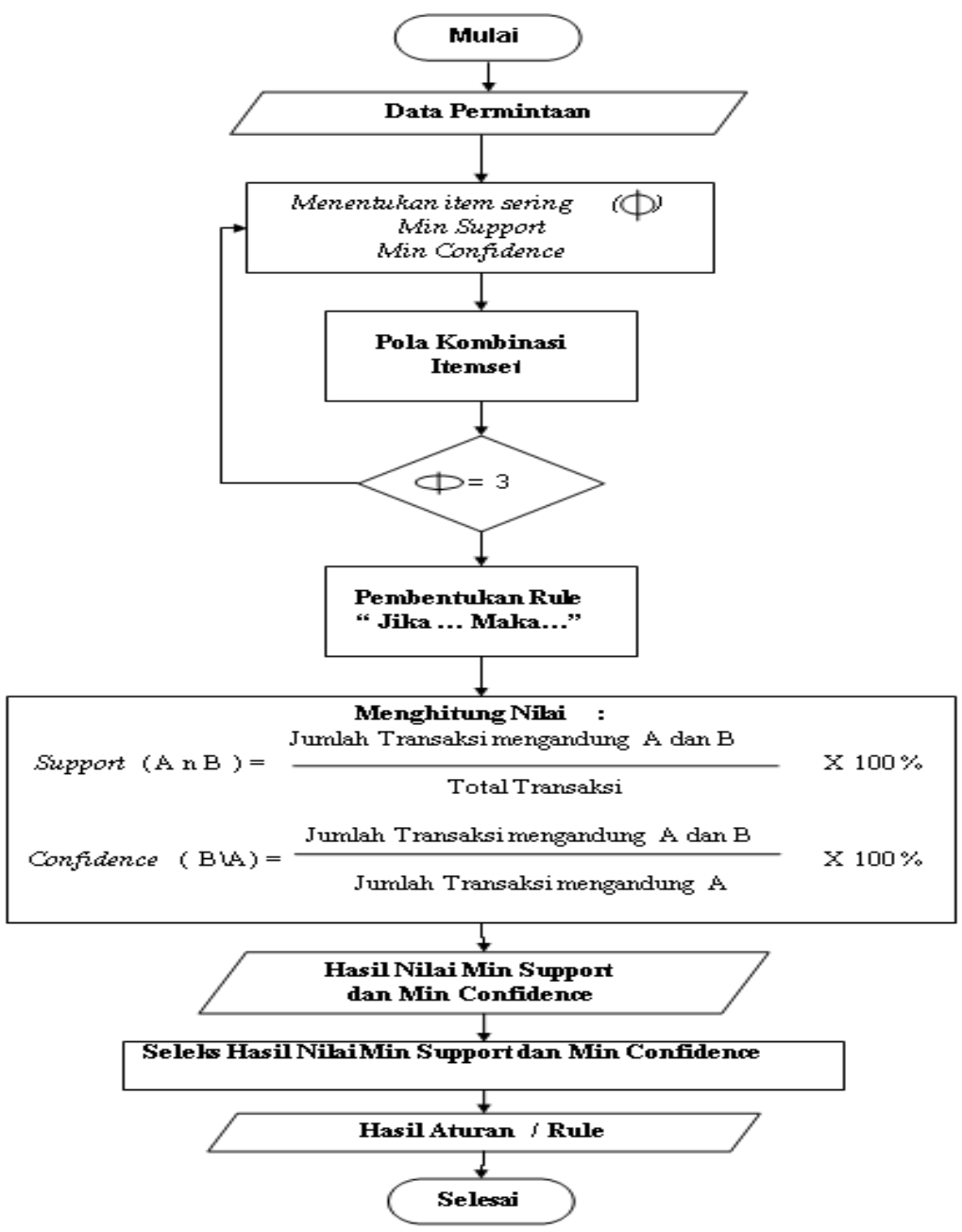

Gambar 1. Flowchart Metode Market Basket Analysis

\subsection{Pembahasan}

market basket analysis adalah suatu metodologi untuk melakukan analisis buying habit konsumen dengan menemukan asosiasi antar beberapa item yang berbeda, yang diletakkan konsumen dalam shopping basket (keranjang belanja) yang dibeli pada suatu transaksi.

Adapun langkah dalam menganalisa pola permintaan pemasangan CCTV dengan menggunakan metode market basket analysis yaitu sebagai berikut :

1. Langkah pertama untuk menghitung market basket analysis adalah penginputan data terlebih dahulu. Data yang di input berdasarkan dari hasil riset yaitu data dari CV. Mitra Jaya Perkasa untuk transaksi dan item camera dengan sampel berjumlah 10 transaksi dan 20 item barang yang diminta periode januari 2018. Data tersebut dapat dilihat pada tabel 1. : 
Tabel 1. Jenis kamera CCTV

\begin{tabular}{lll}
\hline No. & Kode Camera & Item Camera \\
\hline 1 & C001 & PTZ CAMERA \\
2 & C002 & DOME CAMERA \\
3 & C003 & BULLET CAMERA \\
4 & C004 & BOX CAMERA \\
5 & C005 & DAY/ NIGHT CAMERA \\
6 & C006 & SPY CAMERA \\
7 & C007 & IP CAMERA \\
8 & C008 & WIRELESS CAMERA \\
9 & C009 & HD CAMERA \\
10 & C010 & IR CAMERA \\
11 & C011 & OUTDOOR CAMERA \\
12 & C012 & CAMOUFLAGE CAMERA \\
13 & C013 & CAMERA CCTV ANALOG \\
14 & C014 & CAMERA CCTV DIGITAL \\
15 & C015 & MOTORIZED CAMERA \\
16 & C016 & FIXED CAMERA \\
17 & C017 & INDOOR CAMERA \\
18 & C018 & STANDART DAY CAMERA \\
19 & C019 & CCTV TANPA KABEL \\
20 & C020 & \\
\hline
\end{tabular}

Tabel 2. Data Pemasangan CCTV

\begin{tabular}{ll}
\hline Transaksi & Item / CCTV yang Dibeli \\
\hline 1 & BOX CAMERA, HD CAMERA, CAMERA CCTV DIGITAL \\
2 & PTZ CAMERA, BOX CAMERA, MOTORIZED CAMERA \\
3 & BOX CAMERA, SPY CAMERA, WIRELESS CAMERA, MOTORIZED CAMERA \\
4 & BOX CAMERA, SPY CAMERA, WIRELESS CAMERA, CAMERA CCTV DIGITAL \\
5 & PTZ CAMERA, WIRELESS CAMERA, HD CAMERA, MOTORIZED CAMERA \\
6 & PTZ CAMERA, WIRELESS CAMERA, MOTORIZED CAMERA \\
7 & BOX CAMERA, SPY CAMERA, WIRELESS CAMERA \\
8 & HD CAMERA, CAMERA CCTV DIGITAL \\
9 & PTZ CAMERA, WIRELESS CAMERA, MOTORIZED CAMERA \\
10 & BOX CAMERA, CAMERA CCTV DIGITAL \\
\hline
\end{tabular}

2. Kemudian pisahkan masing - masing item barang yang diminta dari setiap transaksi dengan kodenya masing masing, dan Data tersebut dapat dilihat pada tabel 3. :

\begin{tabular}{lll} 
& & \multicolumn{1}{c}{ Tabel 3. Jenis camera yang ada ditransaksi } \\
\hline No. & Kode Camera & Item Camera \\
\hline 1 & C001 & PTZ CAMERA \\
2 & C004 & BOX CAMERA \\
3 & C007 & SPY CAMERA \\
4 & C009 & WIRELESS CAMERA \\
5 & C010 & HD CAMERA \\
6 & C015 & CAMERA CCTV DIGITAL \\
7 & C016 & MOTORIZED CAMERA \\
\hline
\end{tabular}

3. Selanjutnya setelah dipisahkan kemudian akan dibuat tabel untuk mengetahui item camera apa saja yang diminta oleh setiap bulannya Data tersebut dapat dilihat pada tabel 4. :

Table 4. Camera yang diminta Oleh Transaks

\begin{tabular}{|c|c|c|c|c|c|c|c|c|c|c|c|c|}
\hline \multirow{2}{*}{ Transaksi } & \multicolumn{12}{|c|}{ Kode Item Camera } \\
\hline & C001 & $\mathrm{CO02}$ & $\mathrm{CO03}$ & $\mathrm{C004}$ & $\mathrm{C005}$ & C006 & $\mathrm{C007}$ & $\mathrm{C008}$ & C009 & C010 & C011 & $\mathrm{C012}$ \\
\hline 1 & 0 & 0 & 0 & 1 & 0 & 0 & 0 & 0 & 0 & 1 & 0 & 0 \\
\hline
\end{tabular}




\begin{tabular}{ccccccccccccc}
$\mathbf{2}$ & 1 & 0 & 0 & 1 & 0 & 0 & 0 & 0 & 0 & 0 & 0 & 0 \\
$\mathbf{3}$ & 0 & 0 & 0 & 1 & 0 & 0 & 1 & 0 & 1 & 0 & 0 & 0 \\
$\mathbf{4}$ & 0 & 0 & 0 & 1 & 0 & 0 & 1 & 0 & 1 & 0 & 0 & 0 \\
$\mathbf{5}$ & 1 & 0 & 0 & 0 & 0 & 0 & 0 & 0 & 1 & 1 & 0 & 0 \\
$\mathbf{6}$ & 1 & 0 & 0 & 0 & 0 & 0 & 0 & 0 & 1 & 0 & 0 & 0 \\
$\mathbf{7}$ & $\mathbf{7}$ & 0 & 0 & 0 & 1 & 0 & 0 & 1 & 0 & 1 & 0 & 0 \\
$\mathbf{8}$ & $\mathbf{8}$ & 0 & 0 & 0 & 0 & 0 & 0 & 0 & 0 & 0 & 1 & 0 \\
$\mathbf{9}$ & $\mathbf{9}$ & 1 & 0 & 0 & 0 & 0 & 0 & 0 & 0 & 1 & 0 & 0 \\
$\mathbf{1 0}$ & $\mathbf{1 0}$ & 0 & 0 & 0 & 1 & 0 & 0 & 0 & 0 & 0 & 0 & 0 \\
\hline
\end{tabular}

Table 4. Camera yang diminta Oleh Transaksi ( lanjutan)

\begin{tabular}{ccccccccc}
\hline \multirow{2}{*}{ Transaksi } & \multicolumn{7}{c}{ Kode Item Camera } \\
\cline { 2 - 9 } & C013 & C014 & C015 & C016 & C017 & C018 & C019 & C020 \\
\hline $\mathbf{1}$ & 0 & 0 & 1 & 0 & 0 & 0 & 0 & 0 \\
$\mathbf{2}$ & 0 & 0 & 0 & 1 & 0 & 0 & 0 & 0 \\
$\mathbf{3}$ & 0 & 0 & 0 & 1 & 0 & 0 & 0 & 0 \\
$\mathbf{4}$ & 0 & 0 & 1 & 0 & 0 & 0 & 0 & 0 \\
$\mathbf{5}$ & 0 & 0 & 0 & 1 & 0 & 0 & 0 & 0 \\
$\mathbf{6}$ & 0 & 0 & 0 & 1 & 0 & 0 & 0 & 0 \\
$\mathbf{7}$ & 0 & 0 & 0 & 0 & 0 & 0 & 0 & 0 \\
$\mathbf{8}$ & 0 & 0 & 1 & 0 & 0 & 0 & 0 & 0 \\
$\mathbf{9}$ & 0 & 0 & 0 & 1 & 0 & 0 & 0 & 0 \\
$\mathbf{1 0}$ & 0 & 0 & 1 & 0 & 0 & 0 & 0 & 0 \\
\hline
\end{tabular}

4. Setelah itu akan ditentukan item sering sebesar $\Phi=3$ kali dengan minimum support sebesar $30 \%$

5. Setelah item sering $\Phi 3$ min support dan min confidence ditentukan maka selanjutnya akan dihitung untuk 1itemset atau itemset pertama untuk menetukan $\mathrm{F}_{1}$ frekuensi pertama, Data tersebut dapat dilihat pada tabel 5. :

Tabel 5. Pencarian nilai support 1 item set

\begin{tabular}{ccccccccccccc}
\hline \multirow{2}{*}{ Transaksi } & \multicolumn{10}{c}{ Kode Item Camera } \\
\cline { 2 - 13 } & C001 & C002 & C003 & C004 & C005 & C006 & C007 & C008 & C009 & C010 & C011 & C012 \\
\hline $\mathbf{1}$ & 0 & 0 & 0 & 1 & 0 & 0 & 0 & 0 & 0 & 1 & 0 & 0 \\
$\mathbf{2}$ & 1 & 0 & 0 & 1 & 0 & 0 & 0 & 0 & 0 & 0 & 0 & 0 \\
$\mathbf{3}$ & 0 & 0 & 0 & 1 & 0 & 0 & 1 & 0 & 1 & 0 & 0 & 0 \\
$\mathbf{4}$ & 0 & 0 & 0 & 1 & 0 & 0 & 1 & 0 & 1 & 0 & 0 & 0 \\
$\mathbf{5}$ & 1 & 0 & 0 & 0 & 0 & 0 & 0 & 0 & 1 & 1 & 0 & 0 \\
$\mathbf{6}$ & 1 & 0 & 0 & 0 & 0 & 0 & 0 & 0 & 1 & 0 & 0 & 0 \\
$\mathbf{7}$ & 0 & 0 & 0 & 1 & 0 & 0 & 1 & 0 & 1 & 0 & 0 & 0 \\
$\mathbf{8}$ & 0 & 0 & 0 & 0 & 0 & 0 & 0 & 0 & 0 & 1 & 0 & 0 \\
$\mathbf{9}$ & 1 & 0 & 0 & 0 & 0 & 0 & 0 & 0 & 1 & 0 & 0 & 0 \\
$\mathbf{1 0}$ & 0 & 0 & 0 & 1 & 0 & 0 & 0 & 0 & 0 & 0 & 0 & 0 \\
\hline JUMLAH & $\mathbf{4}$ & $\mathbf{0}$ & $\mathbf{0}$ & $\mathbf{6}$ & $\mathbf{0}$ & $\mathbf{0}$ & $\mathbf{3}$ & $\mathbf{0}$ & $\mathbf{6}$ & $\mathbf{3}$ & $\mathbf{0}$ & $\mathbf{0}$ \\
\hline SUPPORT & $\mathbf{4 0}$ & $\mathbf{0}$ & $\mathbf{0}$ & $\mathbf{6 0}$ & $\mathbf{0}$ & $\mathbf{0}$ & $\mathbf{3 0}$ & $\mathbf{0}$ & $\mathbf{6 0}$ & $\mathbf{3 0}$ & $\mathbf{0}$ & $\mathbf{0}$ \\
\hline
\end{tabular}

Tabel 5. camera CCTV yang diminta (Lanjutan)

\begin{tabular}{ccccccccc}
\hline Transaksi & \multicolumn{7}{c}{ Kode Item Camera } \\
\cline { 2 - 9 } & C0013 & C0014 & C0015 & C0016 & C0017 & C0018 & C0019 & C0020 \\
\hline $\mathbf{1}$ & 0 & 0 & 1 & 0 & 0 & 0 & 0 & 0 \\
$\mathbf{2}$ & 0 & 0 & 0 & 1 & 0 & 0 & 0 & 0 \\
$\mathbf{3}$ & 0 & 0 & 0 & 1 & 0 & 0 & 0 & 0 \\
$\mathbf{4}$ & 0 & 0 & 1 & 0 & 0 & 0 & 0 & 0 \\
$\mathbf{5}$ & 0 & 0 & 0 & 1 & 0 & 0 & 0 & 0 \\
$\mathbf{6}$ & 0 & 0 & 0 & 1 & 0 & 0 & 0 & 0 \\
$\mathbf{7}$ & 0 & 0 & 0 & 0 & 0 & 0 & 0 & 0 \\
$\mathbf{8}$ & 0 & 0 & 1 & 0 & 0 & 0 & 0 & 0 \\
$\mathbf{9}$ & 0 & 0 & 0 & 1 & 0 & 0 & 0 & 0 \\
$\mathbf{1 0}$ & 0 & 0 & 1 & 0 & 0 & 0 & 0 & 0 \\
\hline Jumlah & 0 & 0 & 4 & 5 & 0 & 0 & 0 & 0 \\
\hline Support & $\mathbf{0}$ & $\mathbf{0}$ & $\mathbf{4 0}$ & $\mathbf{5 0}$ & $\mathbf{0}$ & $\mathbf{0}$ & $\mathbf{0}$ & $\mathbf{0}$ \\
\hline
\end{tabular}


Dari tabel diatas dapat diketahui dengan jumlah transaksi $=10$, maka untuk itemset set pertama atau 1 -itemset semunya berhasil muncul melebiłi $=3$ sehingga frekuensi pertamanya sebagi berikut:

$\mathrm{F}_{1}=\{\{\mathrm{C} 001\},\{\mathrm{C} 004\},\{\mathrm{C} 007\},\{\mathrm{C} 009\},\{\mathrm{C} 010\},\{\mathrm{C} 015\},\{\mathrm{C} 016\}\}$

6. Setelah 1-itemset didapat dilanjukan dengan himpunan 2-itemset dimana setiap item barang dipasangkan masing sampai tidak ada lagi item barang yang dipasangkan kemudian dilakukan penjumlahan untuk item barang yang diminta secara bersama, Data tersebut dapat dilihat pada tabel 6. :

Tabel 6. Pola Kombinasi 2-Itemset

\begin{tabular}{cccc}
\hline \multirow{2}{*}{ No. } & \multicolumn{2}{c}{ Pola Kombinasi 2- Itemset } & Jumlah \\
\cline { 2 - 4 } 1 & Kode Barang 1 & Kode Barang 2 & 1 \\
2 & COB1 & C007 & 0 \\
3 & C001 & C009 & 1 \\
4 & C001 & C010 & 0 \\
5 & C001 & C015 & 4 \\
6 & C001 & C016 & 3 \\
7 & C001 & C007 & 3 \\
8 & C004 & C009 & 3 \\
9 & C004 & C010 & 2 \\
10 & C004 & C015 & 3 \\
11 & C004 & C016 & 0 \\
12 & C004 & C009 & 1 \\
13 & C007 & C010 & 1 \\
14 & C007 & C015 & 1 \\
15 & C007 & C016 & 1 \\
16 & C007 & C010 & 4 \\
17 & C009 & C015 & 2 \\
18 & C009 & C016 & 1 \\
19 & C009 & C015 & 0 \\
20 & C010 & C016 & C016 \\
21 & C010 & & 3 \\
\hline
\end{tabular}

Dari tabel diatas dapat diketahui dengan transaksi $=10$, maka untuk itemset set kedua atau 2-itemset yang berhasil muncul melebihi $=3$ sebanyak 6 pasang sehingga frekuensi keduanya sebagi berikut: $\mathrm{F}_{2}=\{\{\mathrm{C} 004, \mathrm{C} 015\},\{\mathrm{C} 004, \mathrm{C} 007\},\{\mathrm{C} 007, \mathrm{C} 009\},\{\mathrm{C} 001, \mathrm{C} 016\},\{\mathrm{C} 001, \mathrm{C} 009\},\{\mathrm{C} 009, \mathrm{C} 016\},\{\mathrm{C} 004, \mathrm{C} 009\}\}$

7. Dari kombinasi itemset di $\mathrm{F}_{2}$ atau itemset ke-2 yang terpilih kemudian digabungkan menjadi calon 3-itemset. Kemudian itemset - itemset yang digabungkan itemset yang memiliki kesamaan dalam k-1 item pertama, Data tersebut dapat dilihat pada tabel 7. :

Tabel 7. Pola Kombinasi 3-Itemset

\begin{tabular}{ccccc}
\hline \multirow{2}{*}{ No. } & \multicolumn{3}{c}{ Pola Kombinasi 3 - Itemset } & \multirow{2}{*}{ Jumlah } \\
\cline { 2 - 4 } & Kode Barang 1 & Kode Barang 2 & Kode Barang 3 & 1 \\
1 & C004 & C015 & C007 & 1 \\
2 & C004 & C015 & C009 & 1 \\
3 & C004 & C001 016 & 1 \\
4 & C004 & C007 & C016 & 3 \\
5 & C004 & C007 & C009 & 3 \\
6 & C001 & C016 & C009 & 1 \\
7 & C007 & C009 & C015 & 1 \\
8 & C007 & C009 & C004 & 1 \\
9 & C009 & C016 & C015 & 0 \\
10 & C009 & C016 & \\
\hline
\end{tabular}

Dari tabel diatas dapat diketahui dengan transaksi $=10$, maka untuk itemset set ketiga atau 3-itemset yang berhasil muncul melebihi $=3$, sebanyak 2 pasang sehingga frekuensi keduanya sebagai berikut:

$\mathrm{F}_{3}=\{\{\mathrm{C} 007, \mathrm{C} 004, \mathrm{C} 009\},\{\mathrm{C} 001, \mathrm{C} 009, \mathrm{C} 016\}\}$

8. Dari kombinasi itemset di $\mathrm{F}_{3}$ atau itemset ke-3 yang terpilih Kemudian digabungkan menjadi calon 4-itemset. Dimana setiap item barang dipasangkan masing masing sampai tidak ada lagi item berang yang dipasangkan. Kemudian dilakuan penjumlahan item barang yang diminta secara bersama, data tersebut dapat dilihat pada tabel 8.

Tabel 8. Pola Kombinasi 4-Itemset 


\begin{tabular}{|c|c|c|c|c|c|}
\hline \multirow{2}{*}{ No. } & \multicolumn{4}{|c|}{ Pola Kombinasi 3 - Itemset } & \multirow{2}{*}{ Jumlah } \\
\hline & Kode Barang 1 & Kode Barang 2 & Kode Barang 3 & Kode Barang 4 & \\
\hline 1 & $\mathrm{C} 007$ & $\mathrm{C} 004$ & $\mathrm{C} 009$ & $\mathrm{C} 001$ & 0 \\
\hline 2 & $\mathrm{C} 007$ & $\mathrm{C} 004$ & $\mathrm{C} 009$ & $\mathrm{C} 016$ & 1 \\
\hline 3 & $\mathrm{C} 004$ & $\mathrm{C} 009$ & $\mathrm{C} 001$ & $\mathrm{C} 016$ & 0 \\
\hline 4 & $\mathrm{C} 001$ & C009 & $\mathrm{C} 016$ & $\mathrm{C} 007$ & 0 \\
\hline
\end{tabular}

Dari tabel diatas dapat diketahui dengan transaksi $=10$, maka untuk itemset set empat atau 4-itemset tidak ada yang berhasil muncul melebihi $\Phi=3$, didapat $F_{4}=\{\} F_{5}, F_{6}, F_{7}$ dan seterusnya juga himpunan kosong

9. Setelah didapat maka langkah selanjutnya membuat rule yang akan dipakai yaitu " Jika (s) maka (ss-s) " dimana untuk (s) adalah antecedent dan untuk (ss) adalah consequent untuk $\mathrm{F}$ yang tepilih yaitu $\mathrm{F}_{2}$ dan $\mathrm{F}_{3}$

10. Menetukan (ss-s) sebagai antecedent dan (s) sebagai consequent dari $\mathrm{F}_{1}$ dan $\mathrm{F}_{3}$, dimana untuk himpunan $\mathrm{F}_{2}$ yaitu : $\mathrm{F}_{3}=\{\{\mathrm{C} 007, \mathrm{C} 004, \mathrm{C} 009\},\{\mathrm{C} 001, \mathrm{C} 009, \mathrm{C} 016\}\}$

Maka disusun :

a. Untuk $\{\mathrm{C} 007, \mathrm{C} 004, \mathrm{C} 009\}$

1. $(\mathrm{ss}-\mathrm{s})=\{\mathrm{C} 007\}, \mathrm{s}=\{\mathrm{C} 004\}$ didapat, Jika $\mathrm{s}=\{\mathrm{C} 004\}$ maka (ss-s) $=\{\mathrm{C} 007\}$

2. $($ ss-s $)=\{\mathrm{C} 004\}, \mathrm{s}=\{\mathrm{C} 007\}$, didapat, Jika $\mathrm{s}=\{\mathrm{C} 007\}$ maka (ss-s) $=\{\mathrm{C} 004\}$

3. $($ ss-s $)=\{\mathrm{C} 007\}, \mathrm{s}=\{\mathrm{C} 009\}$ didapat, Jika $\mathrm{s}=\{\mathrm{C} 009\}$ maka (ss-s) $=\{\mathrm{C} 007\}$

4. $($ ss-s $)=\{\mathrm{C} 009\}, \mathrm{s}=\{\mathrm{C} 007\}$, didapat, Jika $\mathrm{s}=\{\mathrm{C} 007\}$ maka (ss-s) $=\{\mathrm{C} 009\}$

5. $($ ss-s $)=\{\mathrm{C} 004\}, \mathrm{s}=\{\mathrm{C} 009\}$ didapat, Jika $\mathrm{s}=\{\mathrm{C} 009\}$ maka (ss-s) $=\{\mathrm{C} 004\}$

6. $($ ss-s $)=\{\mathrm{C} 009\}, \mathrm{s}=\{\mathrm{C} 004\}$, didapat, Jika $\mathrm{s}=\{\mathrm{C} 004\}$ maka (ss-s) $=\{\mathrm{C} 009\}$

11. Dari langkah diatas, maka akan didapatkan 12 Rule yang dapat digunakan yaitu :
1. $\quad$ Jika $s=\{\mathrm{C} 007\}$ maka (ss-s) $=\{\mathrm{C} 004\}$
2. Jika $\mathrm{s}=\{\mathrm{C} 004\}$ maka (ss-s) $=\{\mathrm{C} 007\}$
3. Jika $\mathrm{s}=\{\mathrm{C} 007\}$ maka (ss-s) $=\{\mathrm{C} 009\}$
4. Jika $\mathrm{s}=\{\mathrm{C} 009\}$ maka (ss-s) $=\{\mathrm{C} 007\}$
5. Jika $\mathrm{s}=\{\mathrm{C} 004\}$ maka (ss-s) $=\{\mathrm{C} 009\}$
6. Jika $\mathrm{s}=\{\mathrm{C} 009\}$ maka (ss-s) $=\{\mathrm{C} 004\}$
7. Jika $\mathrm{s}=\{\mathrm{C} 001\}$ maka (ss-s) $=\{\mathrm{C} 009\}$
8. Jika $\mathrm{s}=\{\mathrm{C} 009\}$ maka (ss-s) $=\{\mathrm{C} 001\}$
9. Jika $\mathrm{s}=\{\mathrm{C} 001\}$ maka (ss-s) $=\{\mathrm{C} 016\}$
10. Jika $\mathrm{s}=\{\mathrm{C} 016\}$ maka (ss-s) $=\{\mathrm{C} 001\}$
11. Jika $\mathrm{s}=\{\mathrm{C} 009\}$ maka (ss-s) $=\{\mathrm{C} 016\}$
12. Jika $\mathrm{s}=\{\mathrm{C} 016\}$ maka (ss-s) $=\{\mathrm{C} 009\}$

Setelah itu akan dibentuk kandidat atau calon asosiasinya dan mengnghitung support dan confidence dengan

Tabel 9. Daftar calon aturan asosiasi

\begin{tabular}{|c|c|c|c|c|c|}
\hline Dari itemset sering & Dihasilkan aturan asosiasi & Sup & & $\mathrm{Cor}$ & lence \\
\hline$\{\mathrm{C} 007, \mathrm{C} 004, \mathrm{C} 009\}$ & $\begin{array}{l}\text { jika minta C007(SPY camera) maka } \\
\text { minta C004 (BOX camera ) }\end{array}$ & $\begin{array}{l}(3 / 10) \times \\
100 \%\end{array}$ & $30 \%$ & $\begin{array}{c}(3 / 3) \\
X \\
100 \%\end{array}$ & $100 \%$ \\
\hline \multirow{3}{*}{$\mathrm{C} 007, \mathrm{C} 004, \mathrm{C} 009$} & $\begin{array}{l}\text { jika minta C004 (box camera) maka } \\
\text { minta C007(spy camera) }\end{array}$ & $\begin{array}{l}(3 / 10) x \\
100 \%\end{array}$ & $30 \%$ & $\begin{array}{l}(3 / 6) x \\
100 \%\end{array}$ & $50 \%$ \\
\hline & $\begin{array}{l}\text { jika minta C007(SPY camera) maka } \\
\text { minta C009 (wireless camera) }\end{array}$ & $\begin{array}{l}(3 / 10) \times \\
100 \%\end{array}$ & $30 \%$ & $\begin{array}{l}(3 / 3) \times \\
100 \%\end{array}$ & $100 \%$ \\
\hline & $\begin{array}{l}\text { jika minta C009 (wireless camera) maka } \\
\text { akan minta jika minta C007(spy camera) }\end{array}$ & $\begin{array}{l}(3 / 10) \times \\
100 \%\end{array}$ & $30 \%$ & $\begin{array}{l}(3 / 6) x \\
100 \%\end{array}$ & $50 \%$ \\
\hline \multirow[t]{2}{*}{$\mathrm{C} 007, \mathrm{C} 004, \mathrm{C} 009$} & $\begin{array}{l}\text { jika minta C004 (box camera) maka akan } \\
\text { minta jika minta C009(wireless camera) }\end{array}$ & $\begin{array}{l}(3 / 10) \times \\
100 \%\end{array}$ & $30 \%$ & $\begin{array}{l}(3 / 6) x \\
100 \%\end{array}$ & $50 \%$ \\
\hline & $\begin{array}{l}\text { Jika minta } \mathrm{C} 009 \text { (wireless camera) maka } \\
\text { akan minta jika minta C004 (box } \\
\text { camera) }\end{array}$ & $\begin{array}{l}(3 / 10) x \\
100 \%\end{array}$ & $30 \%$ & $\begin{array}{l}(3 / 6) x \\
100 \%\end{array}$ & $50 \%$ \\
\hline \multirow[t]{2}{*}{$\mathrm{C} 001, \mathrm{C} 009, \mathrm{C} 016$} & $\begin{array}{l}\text { jika minta C001 (ptz camera) maka akan } \\
\text { minta jika minta C009(wireless camera) }\end{array}$ & $\begin{array}{l}(3 / 10) \times \\
100 \%\end{array}$ & $30 \%$ & $\begin{array}{l}(3 / 4) x \\
100 \%\end{array}$ & $75 \%$ \\
\hline & $\begin{array}{l}\text { Jika minta } \mathrm{C} 009 \text { (wireless camera) maka } \\
\text { akan minta jika minta C001 (ptz camera) } \\
\text { jika minta C001 (ptz camera) maka akan }\end{array}$ & $\begin{array}{l}(3 / 10) x \\
100 \% \\
(4 / 10) x\end{array}$ & $30 \%$ & $\begin{array}{l}(3 / 6) x \\
100 \%\end{array}$ & $50 \%$ \\
\hline \multirow[t]{2}{*}{$\mathrm{C} 001, \mathrm{C} 009, \mathrm{C} 016$} & $\begin{array}{l}\text { minta jika minta C016(motorized } \\
\text { camera) }\end{array}$ & $100 \%$ & & $\begin{array}{l}(3 / 4) x \\
100 \%\end{array}$ & $75 \%$ \\
\hline & Jika minta C016 (motorized camera) & $(4 / 10) \times$ & $40 \%$ & $(3 / 5) x$ & $\begin{array}{c}60 \% \\
\text { Page } \mid 452\end{array}$ \\
\hline
\end{tabular}


maka akan minta jika minta C001 (ptz 100\%

$100 \%$

camera)

jika minta C009 (wireless camera) maka

$\{\mathrm{C} 001, \mathrm{C} 009, \mathrm{C} 016\}$

akan minta jika minta C016(motorized camera)

Jika minta C016 (motorized camera) maka akan minta jika minta C009 (wireless camera)

$\begin{array}{llll}(4 / 10) \times & 40 \% & \begin{array}{c}(3 / 6) \times \\ 100 \%\end{array} & 50 \\ 100 \% & & & \\ & & (3 / 5) \times & 60 \% \\ 14 / 10) \times & 40 \% & 100 \% & \\ 100 \% & & \end{array}$

12. Setelah didapat kandidat atau calon aturan assosiasi maka selanjutnya akan dipilih calon aasosiasi yang memenuhi nilai minimum support dan minimum confidence. Adapun asosiasi yang memenuhi batasan min (support) $=30 \%$ dan min (confidence) $=70 \%$, sehingga akan rule akhir :

Tabel 10 Daftar aturan asosiasi yang memenuhi syarat $\min ($ support $)=30 \%$ dan $\min ($ confidence $)=70 \%$

\begin{tabular}{|c|c|c|c|c|c|}
\hline Dari itemset sering & Dihasilkan aturan asosiasi & Sup & & & \\
\hline$\{\mathrm{C} 007, \mathrm{C} 004, \mathrm{C} 009\}$ & $\begin{array}{l}\text { jika minta C007(SPY camera) maka } \\
\text { minta C004 (BOX camera ) }\end{array}$ & $\begin{array}{l}(3 / 10) x \\
100 \%\end{array}$ & $30 \%$ & $\begin{array}{c}(3 / 3) \\
X \\
100 \%\end{array}$ & $100 \%$ \\
\hline$\{\mathrm{C} 007, \mathrm{C} 004, \mathrm{C} 009\}$ & $\begin{array}{l}\text { jika minta C007(SPY camera) maka } \\
\text { minta C009 (wireless camera) }\end{array}$ & $\begin{array}{l}(3 / 10) \times \\
100 \%\end{array}$ & $30 \%$ & $\begin{array}{l}(3 / 3) \times \\
100 \%\end{array}$ & $100 \%$ \\
\hline$\{\mathrm{C} 001, \mathrm{C} 009, \mathrm{C} 016\}$ & $\begin{array}{l}\text { jika minta C001 (ptz camera) maka akan } \\
\text { minta jika minta C009(wireless camera) }\end{array}$ & $\begin{array}{l}(3 / 10) \mathrm{x} \\
100 \%\end{array}$ & $30 \%$ & $\begin{array}{l}(3 / 4) \times \\
100 \%\end{array}$ & $75 \%$ \\
\hline$\{\mathrm{C} 001, \mathrm{C} 009, \mathrm{C} 016\}$ & $\begin{array}{l}\text { jika minta C001 (ptz camera) maka akan } \\
\text { minta jika minta C016(motorized camera) }\end{array}$ & $\begin{array}{l}(4 / 10) \times \\
100 \%\end{array}$ & $40 \%$ & $\begin{array}{l}(3 / 4) \times \\
100 \%\end{array}$ & $75 \%$ \\
\hline
\end{tabular}

Dari tabel diatas maka dapat disimpulkan.

1. Jika permintaan pemasangan CCTV Spy camera makan kemungkinan pelanggan akan melakukan permintaan pemasangan CCTV Box camera.

2. Jika permintaan pemasangan CCTV Spy camera makan kemungkinan pelanggan akan melakukan permintaan pemasangan CCTV Wireless camera.

3. Jika permintaan pemasangan CCTV Ptz camera makan kemungkinan pelanggan akan melakukan permintaan pemasangan CCTV Wireless camera.

4. Jika permintaan pemasangan CCTV Ptz camera makan kemungkinan pelanggan akan melakukan permintaan pemasangan CCTV Motorized camera.

\section{KESIMPULAN}

Berdasarkan hasil perancangan sistem yang dilakukan oleh penulis tentang Penerapan Data Mining Untuk Menganalisa Pola Permintaan Pemasangan CCTV Dengan Menggunakan Metode Market Basket Analysis Studi Kasus CV. MITRA JAYA PERKASA, masih banyak kekurangan penulis dalam penyusunan skripsi ini. Dari bab-bab sebelumnya diambil suatu kesimpulan yang merupakan hasil akhir dari penulis yaitu :

1. Dengan Menggunakan Metode Market Basket Analysis CV. Mitra Jaya Perkasa bisa menganalisa pola permintaan pemasangan CCTV dikarenakan dengan metode market basket analysis telah berhasil di terapkan.

2. Market Basket Analysis ini dilakukan dengan mengumpulkan data transaksi Pemasangan CCTV tahun sebelumnya supaya bisa mengetahui pola pemasangan CCTV tersebut dengan cara mengelompokkan antar itemset untuk mengetahui jumlah support mnimum dan nilai confidence.

3. Market Basket Analysis merupakan metode untuk mengetahui pola permintaan pemasangan CCTV dengan menerapkan apalikasi Tanagra 1.4 dan Mikrosoft Exel 2010 sebagai database yang digunakan untuk melakukan pengimputan data.

\section{REFERENCES}

[1] T. Informatika and S. A. Riau, "Analisa Data Mining Menggunakan Market Basket Analysis untuk Mengetahui Pola Beli Konsumen Alkadri Masnur."

[2] M. P. Tana, F. Marisa, I. D. Wijaya, J. T. Informatika, and F. T. U. Widyagama, "Penerapan Metode Data Mining Market Basket Analysis Terhadap Data Penjualan Produk Pada Toko Oase Menggunakan Algoritma Apriori,” vol. 3, no. 2, pp. 17 22, 2018.

[3] Fajar Astuti Hermawati, Data Mining. Yogyakarta: CV. Andi Offset, 2013. 